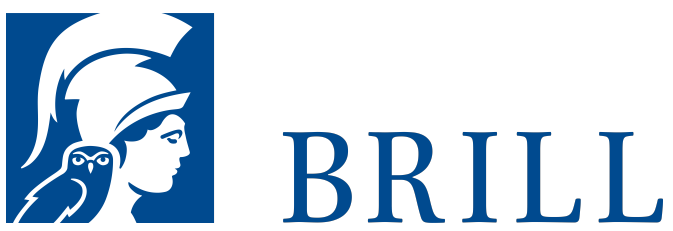

\title{
Musik und Mathematik I
}

\section{Hellas 2: Eros}

Author: Friedrich Kittler

'Wir möchten euch Musik und Mathematik erzählen: das Schönste nach der Liebe, das Schwerste nach der Treue.' Diese beiden Worte, Musik und Mathematik, stehen für die Wurzeln von Kunst und Wissen: musikè, die Lust des Singens, Tanzens, Spielens heißt nach der Muse, die im Herzen alles aufbewahrt und daher davon sagen kann. Aus fast dem selben Ursprung stammt mathesis, das Lehren im Allgemeinen, und Mathematik, das Denken über Zahlen im Besonderen. Unter den wenigen Reimen, die in Griechenohren widerhallen, blieb der alte Spruch von pathein/mathein, leiden und lernen unverloren. Auf 'Aphrodite' und die Welt des Homeros folgen nun 'Eros' und die Polis der Athener. Das misogyne Athen des Euripides, Sokrates und Platon verdrängt Aphrodite (nach Sparta) und huldigt dem Eros, Mathesis trennt sich von Musik und wird zum Flottenbau, aus Nomos, dem archaischen Musikgesetz, wird Numismatik. Timetheos tritt in 'Konzerten', wörtlich also Musikwettkampfspielen, nicht mehr für frische Blumenkränze auf; er singt und spielt für harte Silbermünzen. Wir Sterblichen aber sind blind geworden, als eine Sonne namens Eidos - Sinn, Begriff oder Bedeutung - die Netzhäute verstrahlte von Athen bis Nagasaki. 'Musik und Mathematik', dieser Erinnerung an das homerische Ereignis des griechischen Vokalalphabets, bleibt es auferlegt, Erleuchtungen, die die Göttinnen und Götter sind, vor Platons...

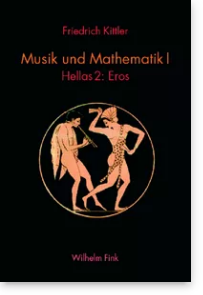

Pages: 414 Seiten, $20 \mathrm{~s} / \mathrm{w}$ Abb.

Language:

German

Subjects:

Ancient

Philosophy,

Philosophy

Publisher: Brill |

Fink

Series:

Friedrich Kittler.

Musik und

Mathematik,

Volume: 1/2

E-Book (PDF)

Released online:

28 Apr 2020

ISBN: 978-3-

8467-4778-о

List price

USD $\$ 71.00$

Hardback

Publication date:

o7 Oct 2009

ISBN: 978-3-

7705-4778-4

List price

USD $\$ 71.00$ 
For more information see brill.com

Order information: Order online at brill.com +44330 333 0049 | customerservices@brill.com Submission information: brill.com/authors

Titles published by Brill | Fink, Brill | mentis or Brill | Schöningh: +49(o)715413279216| brill@brocom.de 